\title{
REGULATION OF EVEN-AGED FORESTS WITH INCLUSION OF ENVIRONMENTAL CONSTRAINTS
}

\author{
Daniel Henrique Breda Binoti ${ }^{1 *}$, Mayra Luiza Marques da Silva Binoti ${ }^{2}$, Helio Garcia Leite ${ }^{1}$, José Marinaldo Gleriani ${ }^{1}$, \\ Márcio Leles Romarco de Oliveira ${ }^{2}$, João Carlos Chagas Campos ${ }^{1}$, Marco Antonio Monte ${ }^{3}$ \\ *Corresponding author: danielhbbinoti@gmail.com
}

\begin{abstract}
This study aimed to propose alternative methods of inclusion of environmental constraints in forest regulation models. Models were constructed for an experimental rural estate with a total planted area of 3.491 ha which was divided into 135 management units. The formulation of the regulation models included integer constraints for all management units. Genetic algorithm metaheuristic was used for solving the models. For comparison purposes, the classical model of forest regulation (model I) was used, and the model with adjacency constraints. The proposed formulations proved to be environmentally more effective than the imposition of adjacency constraints.
\end{abstract}

Key words: Genetic algorithms, adjacency constraints, eucalypt.

\section{REGULAÇÃO DE FLORESTAS EQUIÂNEAS COM INCLUSÃO DE RESTRIÇÕES AMBIENTAIS}

RESUMO: Neste estudo, objetivou-se propor formas alternativas de inclusão de restrições ambientais nos modelos de regulação florestal. Os modelos foram construidos para uma fazenda modelo, com uma área de efetivo plantio de 3.491 ha, divididos em 135 unidades de manejo. Os modelos de regulação foram formulados, incluindo restrições de inteireza para todas as unidades de manejo. Utilizou-se meta-heurística algoritmo genético para a resolução dos modelos. Para efeito de comparação, foi empregado o modelo clássico de regulação florestal (modelo I), e o modelo com restrições de adjacência. As formulações propostas demonstraram ser ambientalmente mais eficientes do que a imposição de restrições de adjacência.

Palavras-chave: Algoritmos genéticos, restrições de adjacência, eucalipto.

\section{INTRODUCTION}

Forest management involves an integrated combination of silvicultural practices and economic concepts aimed at ensuring the objectives of producers are met (BETTINGER et al., 2009). The main challenge of forest management plans today is that they have to continually adapt to environmental changes and social circumstances. This is not trivial since forest growth is a slow process and, therefore, making rapid changes to species and clone composition or to diameter structure and many other traits that affect both the quality and the quantity of services, is usually impossible to achieve (GADOW; PUKKALA, 2008).

In order to adapt regulation models to the social and environmental needs of populations neighboring a forest enterprise, it is important to consider spatial traits (BASKENT; KELES, 2005). A mathematical formulation of social and environmental constraints requires use of integer variables in the representation of management units (MURRAY; CHURCH, 1995).
When establishing a management plan, the selection of silvicultural activities in each management unit will be dependent on the characteristics of neighboring units. For this reason, silvicultural and harvest activities should be oriented both temporally and spatially (BETTINGER et al., 2009). Such orientation is achieved by applying green-up, adjacency or connectivity constraints.

Adjacency constraints seek to minimize environmental impacts brought about by the destruction of natural habitats, thereby preventing harvest in adjacent or extensive contiguous areas while providing shelter and food to animal populations living in the managed forest and also mitigating the visual impacts caused by harvestrelated activities (CASTRO, 2007; MOREIRA, 2008). Such constraints assume that the management unit will regenerate in less than one year. Imposition of green-up constraints occurs whenever the management unit is incapable of regenerating in less than one year (BOSTON; BETTINGER, 2000). And the need for the fauna to shift between different fragments of native forest is met by connectivity constraints (MOREIRA, 2008).

\footnotetext{
${ }^{1}$ Universidade Federal de Viçosa - Viçosa, Minas Gerais, Brazil

${ }^{2}$ Universidade Federal dos Vales do Jequitinhonha e Mucuri - Diamantina, Minas Gerais, Brazil

${ }^{3}$ Universidade Federal Rural do Rio de Janeiro - Seropédica, Rio de Janeiro, Brazil
}

Cerne, Lavras, v. 19, n. 4, p. 29-36, out./dez. 2013 
Adjacency constraints were originally proposed by Thompson et al. (1973), whereby for each pair of adjacent plots in each year of the planning horizon a restriction was formulated (MURRAY; CHURCH, 1996; TORRESROJO; BRODIE, 1990; YOSHIMOTO et al., 1990). Several formulation alternatives were proposed aimed at reducing the number of constraints required to represent the various existing adjacency relationships (MCDILL; BRAZE, 2000).

Implementation of adjacency constraints will result in models that consider a landscape with several management units which in turn differ in their characteristics and are dispersed in space (BASKENT; JORDAN, 1995; GADOW; PUKKALA, 2008).

There are several ways to determine the spatial relationships between different management units, including the extent of common borders between them and the distance between them (BAILEY; GATRELL, 1995; CHEN; GADOW, 2002; KURTTILLA et al., 2002). Where management units have different conformations as to shape and size, the distance between them could be used as a condition for determining the adjacencies (HURME et al., 2007) or else any other trait indicating that such units have mutual influence.

Due to the interdependent nature and complexity of the correlations between the variables, regulation models with integer variables are potentially impossible to solve using classic mathematical programming methods (MCDILL; BRAZE, 2000). As a result, many research studies have been suggesting use of heuristic techniques to solve such problems (BORGES et al., 1999; BOSTON; BETTINGER, 1999; HOGANSON; BORGES, 1998; MURRAY; CHURCH, 1995; NELSON; BRODIE, 1990; WEINTRAUB et al., 1994).

Metaheuristics used for solving adjacency constraint problems include simulated annealing, tabu search and genetic algorithms (BASKENT; JORDAN, 2002; BETTINGER et al., 2002, 2003, 2009; BOSTON; BETTINGER, 1999; BRUMELLE et al., 1998; CARO et al., 2003; CHEN; GADOW, 2002; CROWE; NELSON, 2003; DEUSEN, 2001; MULLEN; BUTLER, 1997; MURRAY; CHURCH, 1995; OHMAN; ERIKSSON, 2002). Some findings suggest that genetic algorithms are more effective than other search heuristics in solving problems with complex spatial objectives.

On account of the complexity of regulation models with spatial constraints, this study was designed to assess and solve a mathematical regulation model ultimately looking to reduce the negative environmental impacts of a forest enterprise.

\section{MATERIAL AND METHODS}

Mathematical models were formulated in order to: 1. minimize the harvest area index (IAC);

2. maximize the total net present value (VPL) by applying penalties as a function of the IAC.

Assessment of the best modeling alternatives was done as a function of VPL and IAC.

\subsection{Data}

Data were obtained from an experimental rural estate where a case study was implemented to represent a situation found in a forest company of central-eastern Minas Gerais state. The total area of the rural estate is around 9.750 ha, of which $35 \%$ (3.412 ha) is effectively cultivated while the remaining part consists of a legal reserve and permanent preservation areas. The site was divided into 135 management units according to administrative, soil, climate and physiographic traits. The distribution of the management units and respective age classes are illustrated in Figure 1.

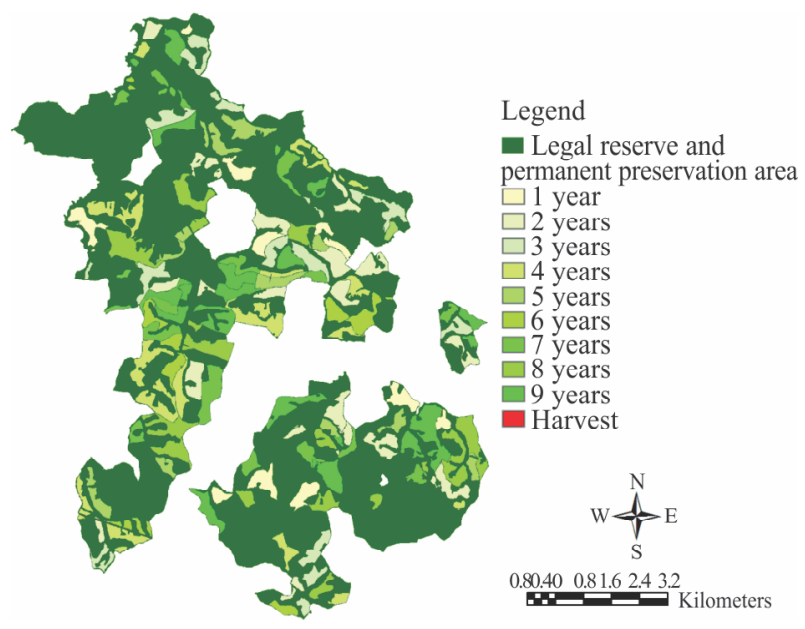

Figure 1 - Spatial distribution of age classes across the experimental rural estate.

Figura 1 - Distribuição espacial de classes de idade das áreas da Fazenda modelo utilizada.

\subsection{Mathematical models}

The model was formulated using the optimized forest planning system SifPlan (www.treesoftware.com.br). 
The approach adopted for generating management units was that of model I, according to Johnson and Scheurman (1977), using binary variables for the decision variables, as is illustrated next.

Objective Function:

$$
\begin{aligned}
& M A X Z=\sum_{i=1}^{m} \sum_{j=1}^{n} c_{i j} x_{i j} \\
& \text { Subject to: } \\
& \sum_{i=1}^{m} \sum_{j=1}^{n} x_{i j}=1 \\
& \sum_{i=1}^{m} \sum_{j=1}^{n} V_{i j} x_{i j} \geq \operatorname{Dmin}_{k}\{k=0,1, \ldots, H-1\} \\
& \sum_{i=1}^{m} \sum_{j=1}^{n} V_{i j} x_{i j} \leq \operatorname{Dmax}_{k}\{k=0,1, \ldots, H-1\} \\
& \sum_{l=1}^{I R} A_{l k}=\left(\frac{\text { totalarea }}{R}\right)\{k=H-1\} \\
& x_{i j} \in\{0,1\}
\end{aligned}
$$

where $\mathrm{Z}=$ total net present value $(\mathrm{R} \$) ; x_{i j}=$ decision variables, representing the $j$-th management alternative adopted in the $i$-th management unit; $c_{i j}=$ net present value of each management unit $i$, as managed according to management alternative $j ; m=$ total number of management units; $n=$ total number of management alternatives in the $i$-th management unit; $V_{i j k}=$ volume $\left(\mathrm{m}^{3}\right)$ produced by the $i$-th management unit when the $j$-th management alternative is adopted, for period $k ; \operatorname{Dmin}_{k}$ and $\operatorname{Dmax}_{k}=$ minimum and maximum volume requirement $\left(\mathrm{m}^{3}\right)$, respectively, in each period of the planning horizon; $A_{l k}$ represents the area of the stand at age $l$ and period $k$; and $\mathrm{R}$ is the regulating age.

According to this integer programming model, maximization of $Z(1)$ is subject to singularity constraints (2) and (6) and to minimum (3) and maximum (4) outputs in each period of the planning horizon. Constraint (5) ensures establishment of the forest regulation. The planning horizon was defined as with 1.5 cycle, as suggested by Leuschener (1984), adopting a rotation of 6 years and a cycle of 2 rotations, the planning horizon thus being 18 years. The maximum and minimum imposed annual volume requirements were 150,000 and $200,000 \mathrm{~m}^{3}$ respectively.

Interventions in stands included harvest, immediately followed by replanting, or harvest with replanting in the next period, meaning that only one management regime was evaluated (high forest). Harvest age was made possible to vary between 5-9 years within the planning horizon, with a regulatory rotation length of
6 years. For purposes of comparison, the same model was obtained without inclusion of adjacency constraints and age class constraints restrictions per cell.

The optimization procedure was performed using genetic algorithm metaheuristic (GA), with a computational routine developed in the programming environment Visual Basic for Applications combined with Software Microsoft Excel. The solutions (individuals) generated for the problem in question had the following vector format $V(x)=\left\{X_{11}, X_{12}, \ldots, X_{i j}\right\}$, in which the decision variable $X_{i j}\left(X_{i j} \in\{0,1\}\right)$ symbolizes management alternative $j(j=1,2, \ldots, n)$ assigned to management unit $i$ ( $i$ $=1,2 \ldots m)$ (RODRIGUES et al., 2004).

The initial population of the GA consisted of 30 randomly generated individuals, considering the viability of each solution by the singularity constraint. The evolution of the genetic algorithm depends on mechanisms known as genetic operators which are responsible for changes in the population, generating improved populations over time. Multiple-point crossover and a mutation rate of $0.6 \%$ were used for each individual of the population, with selection of individuals being based on elitism. The algorithm run was terminated when, with fitness stabilized, the GA produced 20 new generations.

\subsection{Assessment of dispersion of interventions in management units}

Among the various metrics described in literature for assessing landscape management (BASKENT; JORDAN, 1995), the choice in this study was to assess the effect of adjacency constraint by the weighted average of the square of the inverse of the smallest distance between the management units harvested in the same period, subject to the square areas of the management units under intervention. The index used was:

$I A C=\frac{\sum_{k=0}^{H-1} \sum_{i=1}^{m} A_{i}^{2}\left(\frac{1}{d_{i}}\right)^{2}}{\sum_{i=1}^{m} A_{i}}$

where $I A C=$ harvest area index, $A_{i}=$ area of management unit $i$ under intervention, in $\mathrm{m}^{2}, d_{i}=$ distance to the nearest management unit under intervention, in meters.

\subsection{Adjacency constraint}

A model was developed for comparison in which classic adjacency restrictions were applied. Due to the very rugged relief of the study site, the management units

Cerne, Lavras, v. 19, n. 4, p. 29-36, out./dez. 2013 
were considered to be adjacent when the distance between their boundaries (edges) was $50 \mathrm{~m}$ or less. The adjacency constraint to avoid harvest in adjacent management units was:

$$
n_{i} x_{i j}+\sum_{i \in N_{i}} x_{i j} \leq n_{i} \forall i, k
$$

where $n_{i}$ refers to the number of adjacent management units with harvest in period $k$ (MCDILL; BRAZE, 2000).

\subsection{IAC minimization}

IAC minimization was used as objective function. Optimization was done using genetic logarithm metaheuristic, the fitness function being as follows:

$\operatorname{Max} Z=\frac{\sum_{k=0}^{H-1} \sum_{i=1}^{m} A_{i}^{2}\left(\frac{1}{d_{i}}\right)^{2}}{\sum_{i=1}^{m} A_{i}}-\alpha\left(H_{k}-\sum_{i=1}^{m} \sum_{j=1}^{n} V_{i j} x_{i j}\right)-\gamma\left(A_{i}-\sum_{i=1}^{m} A_{i} x_{i}\right)^{2}$

where $\mathrm{Z}=$ value of the fitness function; $x_{i j}=$ decision variables, representing the $j$-th management alternative adopted in the $i$-th management unit; $c_{i j}=$ net present value of each management unit $i$, as managed according to management alternative $j ; m=$ total number of management units; $n=$ total number of management alternatives in the $i$-th management unit; $V_{i j k}=$ volume $\left(\mathrm{m}^{3}\right)$ produced by the $i$-th management unit when the $j$-th management alternative is adopted for period $k ; H_{k}=$ volume requirement $\left(\mathrm{m}^{3}\right)$ in each period of the planning horizon; $\alpha, \beta$ and $\gamma$ are penalty coefficients associated with each constraint; $A_{l k q}$ refers to areas of cell $q$ harvested in period $k ; A_{l}=$ regulatory area and $A_{i}=$ area of management unit $i$.

\subsection{VPL maximization with penalties as a function of the IAC}

The fitness function of the genetic algorithm used in this model was based on application of penalties to the objective function, consisting of maximizing the total net present value. Penalties were imposed as a function of percentages $(\mu)$ of VPL and IAC. Percentages ranged at a $5 \%$ rate with an initial value of $5 \%$ and a maximum value of $100 \%$. The fitness function used for this model was:

\subsection{Output, Revenue and Cost}

$\operatorname{Max}=\sum_{i=1}^{m} \sum_{j=1}^{n} c_{i j} x_{i j}-\alpha\left(H_{k}-\sum_{i=1}^{m} \sum_{j=1}^{n} V_{j} x_{i j}\right)-\mu\left(\sum_{i=1}^{m} \sum_{j=1}^{n} c_{i j} x_{i j}\right)\left(\frac{\left(\sum_{k=1}^{m-1} \sum_{i=1}^{m} A_{i}^{2}\left(\frac{1}{d_{i}}\right)^{2}\right)}{\sum_{i=1}^{m} A_{i}}\right)^{2}\left(A_{i}-\sum_{i=1}^{m} A_{i} x_{i}\right)^{2}$
One hybrid clone (Eucalyptus urophylla $\mathrm{x}$ Eucalyptus grandis) was considered as being the sole source of timber used. The output curve obtained from plot data of a forest inventory was:

Volume $=\frac{197.833}{1+75.674 e^{-1.315 \text { Age }}}$

The costs table used in the analyses was obtained from Binoti 2010. The interest rate used was $8.75 \%$ a year and the timber sale value was $\mathrm{R} \$ 80.00 / \mathrm{m}^{3}$.

\section{RESULTS}

Formulation of the regulation model generated a problem with 8,755 decision variables. In all forest regulation problems, satisfactory results were obtained for the regulation constraints and annual volume variation.

Imposition of adjacency constraints reduced the total VPL by around $8 \%$. The value of the objective function for the models with and without inclusion of adjacency constraints were $\mathrm{R} \$ 17,143,857.17$ and $\mathrm{R} \$$ $18,599,169.37$ respectively.

IAC minimization resulted in a VPL of $R \$$ 17,322,217.40. Variations in VPL and IAC corresponding to the models with VPL maximization with penalties imposed as a function of IAC and distance between harvested units, are provided in Figure 2.

The IAC value for the model, with and without inclusion of the adjacency constraint, was 0.246436 and 0.615032 respectively. Using models with IAC minimization resulted in an index of 0.176432 . The influence of applying IAC penalties is illustrated in Figure 3 , noting that penalties above $20 \%$ resulted in better models environmentally and landscape wise (lower IAC), with improved economic returns (higher VPL).

\section{DISCUSSION}

The description of the forest management model was rapidly expanded from traditional timber production to sustainable production of multiple services (BASKENT; JORDAN, 1995). Such changes added characteristics even more complex and difficult to solve to forest regulation models.

Preference for scenically beautiful landscapes is a value inherent in people and such values vary from one socioeconomic group to another. With that in mind, it is important to consider the scenic beauties of a forest

Cerne, Lavras, v. 19, n. 4, p. 29-36, out./dez. 2013 


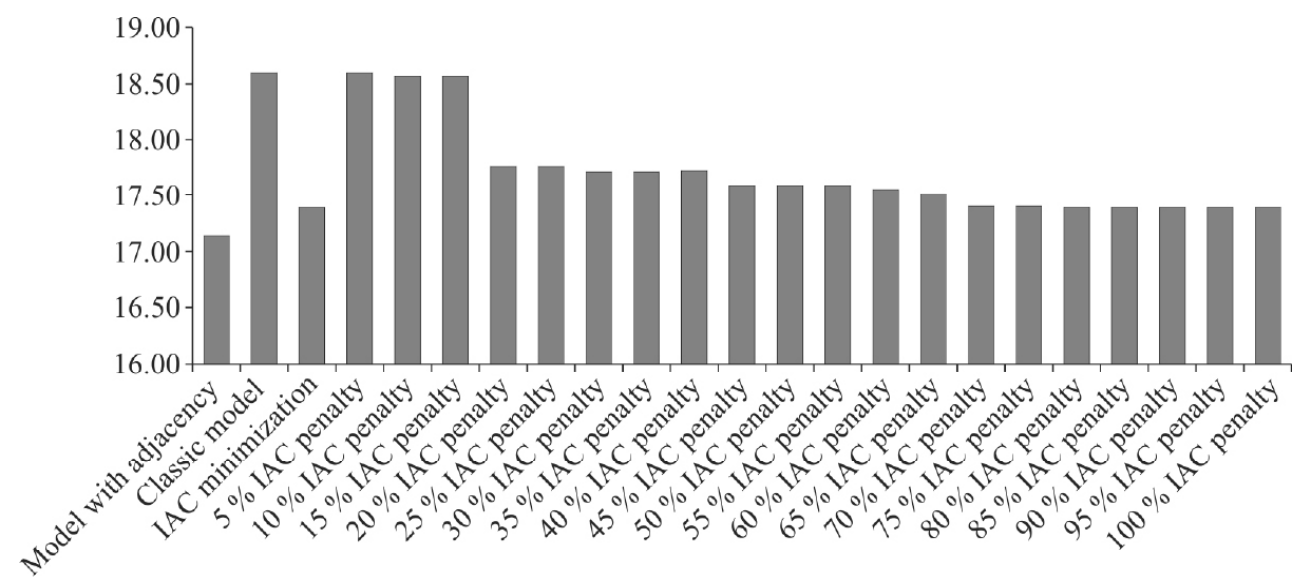

Figure 2 - VPL (in millions of Brazilian reais) for each regulation model as derived from various modeling methods (adjacency, classic, IAC minimization, VPL maximization with penalties as a function of IAC).

Figura 2 - VPL(em milhões de Reais) para cada modelo de regulação gerado nas diversas formas de modelagem (adjacência, clássico, minimização do IAC, maximização do VPL com penalidades em função do IAC).

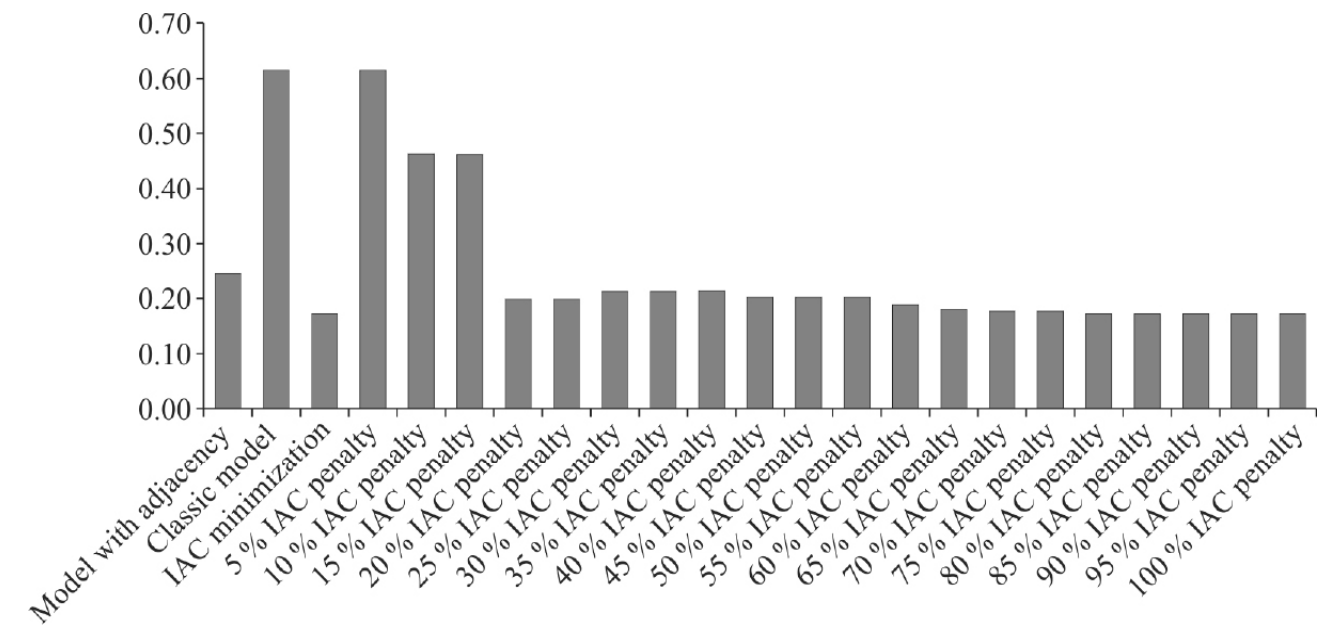

Figure 3 - IAC for each regulation model as derived from various modeling methods (adjacency, classic, IAC minimization, VPL maximization with penalties as a function of the IAC).

Figura 3 - IAC para cada modelo de regulação gerado nas diversas formas de modelagem (adjacência, clássico, minimização do $I A C$, maximização do VPL com penalidades em função do IAC).

when developing forest management plans (BETTINGER et al., 2009).

Inclusion of environmental and landscape restrictions is mainly done by imposing adjacency constraints. Constraints consist of controlling interactions between management units within a forest in such way that harvest activities in one management unit will restrict harvest actions in neighboring or adjacent units (MURRAY; CHURCH, 1995). They also prevent formation of large contiguous harvested areas. Imposition of constraints entails a considerably increased computational effort, requiring long hours, if not days, to solve problems with relatively few management units using classic integer programming algorithms (MCDILL; BRAZE, 2000). For this reason, many research studies have been conducted to try and reduce the processing time involved in solving such problems.

Cerne, Lavras, v. 19, n. 4, p. 29-36, out./dez. 2013 
Adjacency constraints were originally formulated by Thompson et al. (1973), with one constraint formulated for each pair of adjacent plots. Subsequent studies based on this type of formulation resulted in significant reductions in the processing time (MCDILL; BRAZE, 2000). Besides the considerable dimension a regulation model acquires with imposition of this type of constraint, obtaining a feasible solution to the problem while meeting all constraints is many a time unenforceable.

The index used for models comparison is extremely simple and easy to obtain with application of Geographic Information Systems (GIS) or mapping techniques. The index was found to be consistent with assumptions adopted for management of even-aged plantation landscapes. The index is directly proportional to the area under intervention and inversely proportional to the distance between management units under intervention, weighted by the annual harvest area. In practical terms, the closer it is to zero, the better the environmental and socioeconomic influences will be on neighboring communities and ecosystems.

The purpose of this study was to introduce alternative methods for solving regulation problems with inclusion of environmental and landscape constraints. The proposal of IAC minimization resulted in an IAC value lower by $17 \%$ than the result found by the model with adjacency constraint and in a VPL value higher by around $2 \%$. IAC minimization revealed economic and environmental superiority in relation to the model with adjacency constraints. Application of IAC penalties above $20 \%$ on VPL maximization resulted in better IAC values than the adjacency model and higher VPL values, being thus preferred to models with adjacency constraints. The reduction in the magnitude of the regulation model, the ease of modeling and the increased environmental benefits did favor IAC minimization as an alternative for forest regulation models.

\section{REFERENCES}

BAILEY, T. C.; GATRELL, A. C. Interactive spatial data analysis. London: A. W. Longman, 1995.

BASKENT, E. Z.; JORDAN, G. A. Characterising spatial structure of forest landscape. Canadian Journal of Forest Research, Ottawa, v. 25, p. 18301849, 1995.

BASKENT, E. Z.; JORDAN, G. A. Forest landscape management modelling using simulated annealing. Forest

Cerne, Lavras, v. 19, n. 4, p. 29-36, out./dez. 2013
Ecology and Management, Amsterdam, v. 165, p. 2945,2002.

BASKENT, E. Z.; KELES, S. Spatial forest planning: a review. Ecological Modelling, Amsterdam, v. 188, p. 145173, 2005.

BETTINGER, P.; BOSTON, K.; SIRY, L. P.; GREBNER, R. L. Forest management and planning. New York: Elsevier, 2009. $331 \mathrm{p}$.

BETTINGER, P.; GRAETZ, D.; BOSTON, K.; SESSIONS, J.; CHUNG, W. Eight heuristic planning techniques applied to three increasingly diffcult wildlife planning problems. Silva Fennica, Helsinski, v. 36, p. 561-584, 2002.

BETTINGER, P.; JOHNSON, D. L.; JOHNSON, K. N. Spatial forest plan development with ecological and economic goals. Ecological Modelling, Amsterdam, v. 169, n. 2/3, p. 215-236, 2003.

BORGES, J. G.; HOGANSON, H. M.; ROSE, D. W. Combining a decomposition strategy with dynamic programming to solve spatially constrained forest management scheduling problems. Forest Science, Bethesda, v. 45, p. 201$212,1999$.

BOSTON, K.; BETTINGER, P. The economic impact of greenup constraints in the southeastern United States. Forest Ecology and Management, Amsterdam, v. 145, p. 191202, 2001.

BRUMELLE, S.; GRANOT, D.; HALME, M.; VERTINSKY, I. A tabu search algorithm for finding good forest harvest schedules satisfying green-up constraints. European Journal of Operational Research, Amsterdam, v. 106, n. 2/3, p. 408424, 1998.

CARO, F.; CONSTANTINO, M.; MARTINS, I.; WEINTRAUB, A. A 2- opt tabu search procedures for the multiperiod forest harvesting problem with adjacency, greenup, old growth, and even flow constraints. Forest Science, Bethesda, v. 49, n. 5, p. 738-751, 2003.

CASTRO, R. R. Regulação de florestas equiâneas incluindo restrições de adjacência. 2007. 64 f. Dissertação (Mestrado em Ciência Florestal) - Universidade Federal de Viçosa, Viçosa, 2007.

CHEN, V. B. W.; GADOW, K. V. Timber harvest planning with spatial objectives, using the method of simulated annealing. Forstwissenschaftliches Centralblatt, Berlin, v. 
121, p. 25-34, 2002.

CROWE, K.; NELSON, J. An indirect search algorithm for harvest scheduling under adjacency constraints. Forest Science, Bethesda, v. 49, n. 1, p. 1-11, 2003.

DEUSEN, P. C. van. Scheduling spatial arrangement and harvest simultaneouly. Silva Fennica, Helsinski, v. 35, n. 1, p. 85-92, 2001.

GADOW, K. V.; PUKKALA, T. (Ed.). Designing green landscapes. New York: Springer, 2008. (Springer Series "Managing. Forest Ecosystems", 15).

HOGANSON, H. M.; BORGES, J. G. Using dynamic programming and overlapping subproblems to address adjacency in large harvest scheduling problems. Forest Science, Bethesda, v. 44, p. 526-538, 1998.

HURME, E.; KURTTILA, M.; MÖNKKÖNEN, M.; HEINONEN, T.; PUKKALA, T. Maintenance of flying squirrel habitat and timber harvest: a site specific spatial model in forest planning calculations. Landscape Ecology, Dordrecht, v. 22, n. 2, p. 243-256, Feb. 2007.

JOHNSON, K. N.; SCHEURMAN, H. L. Techniques for prescribing optimal timber harvest and investment under different objectives discussion and synthesis. New York: Springer, 1977. (Forest Science Monograph, 18).

KURTTILA, M.; PUKKALA, T.; LOIKKANEN, J. The performance of alternative spatial objective types in forest planning calculations: a case for flying squirrel and moose. Forest Ecology and Management, Amsterdam, v. 166, p. 245-260, 2002.

LEUSCHNER, W. A. Introduction to forest resource management. New York: J. Wiley, 1984. 284 p.

MCDILL, M. E.; BRAZE, J. Comparing adjacency constraint formulations for randomly generated forest planning problems with four age-class distributions. Forest Science, Bethesda, v. 46, p. 423-436, 2000.

MOREIRA, J. M. M. A. P. A incorporação de corredores de conectividade em problemas de otimização para o planejamento de florestas industriais. 2008. $123 \mathrm{f}$. Dissertação (Doutorado em Economia Aplicada) - Escola Superior de Agricultura “Luiz de Queiroz”, Piracicaba, 2008.

MULLEN, D. S.; BUTLER, R. M. The design of a genetic algorithm based spatially constrained timber harvest scheduling model. Disponível em: < http://www.for.msu.edu/ e4/e4 ssafr97.html>. Acesso em: 10 dez. 1997.

MURRAY, A. T.; CHURCH, R. L. Analyzing cliques for imposing adjacency restrictions in forest models. Forest Science, Bethesda, v. 42, p. 166-175, 1996.

MURRAY, A. T.; CHURCH, R. L. Heuristic solution approaches to operational forest planning problems. Operation Research Spektrum, Berlin, v. 17, p. 193-203, 1995.

NELSON, J.; BRODIE, J. D. Comparison of random search algorithm and mixed integer programming for solving areabased forest plans. Canadian Journal of Forest Research, Ottawa, v. 20, p. 934-942, 1990.

ÖHMAN, K.; ERIKSSON, L. O. Allowing for spatial consideration in longterm forest planning by linking linear programming with simulated annealing. Forest Ecology and Management, Amsterdam, v. 161, p. 221230, 2002.

RODRIGUES, F. L.; LEITE, H. G.; SANTOS, H. N.; SOUZA, A. L.; SILVA, G. F. Metaheuristica algoritmo genetic para solução de problemas de planejamento florestal com restrições de integridade. Revista Árvore, Viçosa, v. 22, n. 2 , p. 233-245, mar./abr. 2004.

THOMPSON, E. F.; HALTERMAN, B. G.; LYON, T. J.; MILLER, R. L. Integrating timber and wildlife management planning. The Forestry Chronicle, Ottawa, v. 49, n. 6, p. 247-250, 1973.

TORRES-ROJO, J. M.; BRODIE, J. D. Adjacency constraints in harvest scheduling: an aggregation heuristic. Canadian Journal of Forest Research, Ottawa, v. 20, p. 978-986, 1990.

WEINTRAUB, A.; BARAHONA, F.; EPSTEIN, R. A column generation algorithm for solving general forest planning problems with adjacency constraints. Forest Science, Bethesda, v. 40, p. 142-161, 1994.

YOSHIMOTO, A.; HAIGHT, R. G.; BRODIE, J. D. A comparison of the pattern search algorithm and the modified PATH algorithm for optimizing an individual tree model. Forest Science, Bethesda, v. 36, n. 2, p. 394-412, 1990.

Received: April 14, 2011; accepted: April 16, 2013.

Cerne, Lavras, v. 19, n. 4, p. 29-36, out./dez. 2013 
